\title{
SCAI Fall Fellows Courses - zpráva z workshopu intervenční kardiologie
}

Ve dnech 5.-9. 12. 2011 se v Las Vegas (Nevada, USA) konaly každoroční kursy pro začínající intervenční kardiology pořádané Society for Cardiovascular Angiography and Interventions (SCAI). Paralelně probíhaly přednášky v sekcích pro intervenční kardiologii dospělých, resp. intervence u pacientů s vrozenými srdečními vadami.

Pondělní odpoledne 5.12 . bylo věnováno firemním symposiím a pre-workshopům. Úterní program zahájil prezident SCAI Christopher J. White, který zdůraznil pevné postavení perkutánních intervencí $v$ terapii kardiovaskulárních nemocí, např. významné a pevnější postavení nových generací lékových stentů (DES) v léčbě ICHS, angioplastiky jako metody první volby v terapii kritické končetinové ischemie. $\mathrm{V}$ terapii stenóz renálních tepen nahrazují stenty chirurgické řešení a rovněž v léčbě aneurysmat abdominální aorty dominují intervenční výkony. Dále nastínil neskromnou budoucnost intervencí v náhradách aortální chlopně, převaze stentingu před endarterektomií karotid, renální denervaci při léčbě rezistentní hypertenze nebo $v$ rutinním uzávěru ouška levé síně u pacientů s fibrilací síní.

$\checkmark$ dalším přehledovém sdělení se profesor Issam D. Moussa z Mayo Clinic zabýval řešením nemoci více tepen a kmene levé koronární tepny. $\mathrm{V}$ podstatě shrnul nová guidelines American College of Cardiology Foundation (ACCF)/American Heart Association (AHA)/SCAI pro provádění perkutánních koronárních intervencí, která mají být jasným vodítkem v rozhodování o léčbě pacientů, ale zároveň zmínil určité „skryté cílové ukazatele" ve smyslu rozporu mezi výzkumem a praxí. Tázal se, kdo vlastně určí primární cílové ukazatele? Dle jeho sdělení je to v USA na prvním místě Úřad pro kontrolu potravin a léků (FDA), pak vědci organizující klinické studie spolu se statistiky, poté lékaři a na posledním místě je pacient. Je tedy nutno uplatňovat individualizované řešení i s ohledem na přání pacienta.

Přednáška profesora Jamese Hermillera z Heart Center of Indiana byla věnována problematice stentů a nových technologií při jejich výrobě. Úvodem zmínil historický vývoj perkutánních koronárních intervencí (PCI) od prosté balonkové plastiky přes holé kovové stenty (BMS) až po DES poslední generace a dokumentoval jej grafy klesajícího počtu restenóz a minimalizace počtu technického selhání, nutnosti emergentního aortokoronárního bypassu (CABG), trombóz ve stentech a velmi pozdních trombóz. Hlavní nevýhody DES první generace spočívaly v problematickém vhojení stentů - prítomnosti eosinofilních infiltrátů, zpožděném hojení, remodelaci cévy. Lékové stenty druhé generace $s$ everolimem prokázaly lepší výsledky ve výskytu trombóz i velmi pozdních trombóz (everolimus vs. paclitaxel ve studiích SPIRIT II-IV a COMPARE a everolimus vs. sirolimus ve studiích ISARTEST 4, SORT OUT 4), jednoznačný a statisticky významný byl pokles trombóz i velmi pozdních trombóz v Bern-Rotterdam Cohort Study ve prospěch everolimu proti pacli- taxelu i sirolimu. Budoucnost DES spočívá ve vývoji nových antiproliferativních látek nebo v jejich kombinacích, změně kinetiky jejich uvolňování, v nových designech stentů s tenčími struty, v bioresorbovatelných polymerech jako nosičích účinné látky nebo úplné absenci polymerů, které mají prozánětlivý účinek a brání vhojení, anebo $v$ plně bioresorbovatelných stentech.

Další přednášky se týkaly indikací a technických aspektů intervencí u chronických okluzí koronárních tepen, komplexních $\mathrm{PCl}$ a $\mathrm{PCl}$ bifurkačních lézí.

Profesor John S. Douglas z Emory University v Atlantě se věnoval problematice žilních graftů. Příčinou ischemie po CABG může být nekompletní revaskularizace, časné selhání graftu, progrese aterosklerózy nativních tepen, ateromatóza graftu. Ve studii PRAGUE 4 bylo dokumentováno až $41 \%$ zašlých žilních bypassů při operacích on-pump, resp. $51 \%$ při operacích off-pump proti $9 \%$ bypassů $\mathrm{s}$ levou mamární tepnou (LIMA) v jednom roce od operace. Při PCI žilních bypassů je důležitá distální protekce. Při undersizingu stentu bylo zaznamenáno méně akutních infarktů a menší protruze plaku struty stentu dle intravaskulárního ultrazvuku (IVUS). Z řady studií i metaanalýz zatím není zcela jasná preference DES proti BMS u žilních graftů. Perkutánní koronární intervenci nativní tepny je dávána přednost před $\mathrm{PCl}$ graftu.

Pozdní odpoledne každého přednáškového dne byla věnována prakticky zaměřeným workshopům. Na výběr bylo z pěti témat: rotablace, IVUS a frakční průtoková rezerva (FFR), kasuistický seminář, cévní přístupy a trenažér selektivní koronarografie (SKG) a PCl. Atraktivní byl trenažér s možností vyzkoušet si plastiku koronární tepny „nanečisto", ale prakticky nejzajímavější a také nejvíce obsazený byl workshop na téma radiální přístup (který se v USA neužívá tak běžně jako v Evropě) a správná technika femorálního přístupu a jejich komplikace (pseudoaneurysma, retroperitoneální hematom). Velmi zajímavá byla ukázka nové techniky punkce femorální tepny pomocí zařízení Axera (které dosud není v Evropě distribuováno). Technika spočívá v zavedení speciálně tvarované punkční jehly, jejímž lumen se pak provede druhá punkce pod velmi malým úhlem a vytvoří se tak velmi dlouhý kanál, kterým je pak zaveden sheath. Výhoda tohoto systému je pak v rychlém zastavení krvácení po vytažení sheathu (pưsobením arteriálního tlaku dojde k rychlejšímu utvoření trombu v dlouhém punkčním kanálu), kratší doba komprese a na rozdíl od např. systému AngioSeal absence cizího materiálu v místě punkce.

Středeční dopolední program tvořily přednášky na téma periferních a karotických intervencí včetně implantací aortálních stentgraftů. Přednášky byly bohatě dokumentovány kasuistikami. Odpoledne bylo věnováno komplikacím intervencí, jejich zvládání a prevenci.

Profesor John S. Douglas přehledně shrnul problematiku komplikací PCl. Mezi ischemické komplikace patří 
uzávěr tepny a zejména distální embolizace, která způsobí tzv. no-flow nebo slow-flow fenomén. Přítomnost fokální myokardiální nekrózy pomocí MR a vzestupu koncentrace troponinu byla prokázána až u $28 \%$ pacientů po PCl (Selvanayagam a spol., 2005). Nutnost emergentního operačního řešení komplikací se od začátků éry $\mathrm{PCI}$ dramaticky snižuje (Yang, Bautzner, 2005), ale koronární disekce zůstává neopomenutelným problémem i při nejnovějších technikách a instrumentáriu SKG a PCI. Mechanismem při disekci je ruptura plátu při insuflaci balonku nebo rozvinutí stentu, traumatizace intimy guiding katetrem nebo vodičem nebo ruptura balonku. Terapie spočívá bud' v implantaci dalšího stentu/stentů, nebo méně často v chirurgickém řešení. Aortální disekce je vzácnou komplikací, je způsobena nejčastěji guiding katetrem, dělí se do trrí tříd podle lokalizace a řeší se bud' implantací stentu do odstupu koronární tepny, nebo chirurgicky. Perforace koronární tepny rozdělujeme do tří typů podle závažnosti. Nejzávažnější typ 3, kdy je patrný jet kontrastu otvorem o velikosti $1 \mathrm{~mm}$ nebo větším, byl dokumentován v 56 prípadech z $24465(0,23$ \%) z let 1993-2009 (Al-Lamee a spol., 2011), nezávislými prediktory byly komplexní léze, řešení chronických okluzí, použití rotablace a IVUS. Další komplikací může být malpozice stentu vzniklá bud' chybným umístěním, nebo zachycením stentu v proximální lézi, nerozvinutý stent, svlečení stentu o kraj guiding katetru anebo v krajním prípadě ztráta stentu. Dle údajů z Mayo Clinic bylo 38 prípadů ztráty stentu z $11773 \mathrm{PCl}$, v 35 prípadech byl stent úspěšně zachycen (Brilakis a spol., 2005)

Problematice kontrastem indukované nefropatie (CIN) se věnoval Dr. Michael J. Cowley z Virginia Commonwealth University v Richmondu. Zdưraznil nutnost stratifikace rizika dle skórovacích systémů a zejména prevence CIN: v dostatečné hydrataci, v podání co nejmenšího množství nízko- nebo isoosmolárních kontrastních látek, souběžném neužívání kardiotoxické medikace (NSAID, diuretika, aminoglykosidy, ciclosporin, amphotericin B), dostatečné hydrataci - udržovat výdej moči minimálně $150 \mathrm{ml} / \mathrm{h} 6$ hodin po výkonu. Prakticky využitelné jsou vzorce pro výpočet bezpečného množství kontrastní látky u konkrétního pacienta.

1. Poměr objemu kontrastní látky ku clearance kreatininu $(\mathrm{V} / \mathrm{CrCl})>3,7$ je dobrým prediktorem rozvoje CIN (Laskey a spol., 2007).

2. Maximum podané kontrastní látky ( $\mathrm{v} \mathrm{ml}$ ) Ize vypočítat jako $5 \times$ hmotnost pacienta $(\mathrm{kg}) / \mathrm{kreatinin} v$ séru (umol/l) (Marenzi a spol., 2009).

3. Poměr objemu kontrastu ku kalkulované clearance kreatininu (CV/CCC) by měl být < 2-3 (Gurm, 2011).

Podání N-acetylcysteinu ACCF/AHA/SCAI guidelines z roku 2011 nedoporučují (IIIA), i když dle Kellyho metaanalýzy z roku 2008 snížilo riziko CIN o $38 \%$ ( $p<0,0001)$. Testován v této indikaci byl i $\mathrm{NaHCO}_{3}$ - snížil riziko CIN o $61 \%$ proti fyziologickému roztoku (Navaneethan, 2009) - a statiny (ve studii ARMYDA-CIN nesignifikantní snížení rizika proti placebu).

Tématem čtvrtečního dopoledne byly získané srdeční vady a jejich intervenční řešení. Na úvod zazněla před- náška profesora Ziyada M. Hijaziho z Rush Center of Congenital \& Structural Heart Disease v Chicagu o indikacích a technice uzávěru foramen ovale patens a defektů sínového septa s použitím různých druhů systémů dostupných v USA. Technice transseptální punkce se věnoval profesor Clifford J. Kavinsky teké z Rush University Medical Center v Chicagu. Řada přednášek i kasuistik se týkala katetrizační náhrady aortální chlopně (TAVI). Profesor Ted Feldman z Northshore University v Evanstonu podrobně rozebíral studii PARTNER, výhody i nevýhody transfemorálního, transapikálního přístupu nebo klasického operačního řešení. Omezeními u TAVI jsou cévní mozkové příhody, cévní komplikace při femorálním př́stupu, výskyt paravalvulárních regurgitací, větší nutnost zavedení trvalé kardiostimulace a trvanlivost chlopně. Přesto očekává strmý nárůst používání těchto metod. Budoucnost dalších generací aortálních chlopní je ve zmenšení průměru zavaděčů a nových typech a mechanismech chlopní - např. Sadra-BSC Lotus Valve, která díky unikátnímu zámku dovoluje i repozici implantované chlopně, což dosud nejužívanější chlopně Edwards Sapien a CoreValve neumožňovaly. V dalším sdělení se profesor Ted Feldman zabýval katetrizačními náhradami a plastikami mitrální chlopně. Použití MitraClipu ve studii EVEREST II bylo sice méně účinné v redukci mitrální regurgitace než konvenční chirurgické řešení, ale bylo bezpečnější a mělo podobnou míru zlepšení klinických ukazatelů. Možností pro redukci funkční mitrální regurgitace $u$ dilatačních kardiomyopatií je zavedení systému Carillon Mitral Contour - mechanismem je stažení mitrálního prstence cestou koronárního sinu nebo přímá transventrikulární plastika systémem Mitralign. Úplnou katetrizační náhradou je pak systém CardiAQ. Na závěr sdělení profesor Feldman prezentoval působivé kasuistiky pacientů se současně zavedenou aortální chlopní CoreValve a MitraClipem nebo plastikou mitrální chlopně cestou koronárního sinu a MitraClipem nebo transapikálně zavedenou náhradou mitrální i aortální chlopně.

Čtvrteční dopoledne uzavřely přednášky o statistice pro intervenční kardiology a přednáška o kritickém myšlení a základech radiační bezpečnosti. Odpoledne byly prezentovány kasuistiky komplexních a vysoce rizikových $\mathrm{PCl}$.

Na závěr konference $v$ pátek dopoledne zazněly přednášky zaměřené na administrativu intervenčních kardiologů v USA, vykazování a kódování procedur pro potřeby zdravotních pojištoven. Úplným závěrem bylo pak pět kasuistik na téma „Můj nejlepší případ roku 2011", ve kterých nebyla nouze o raritní diagnózy, vysoce rizikové a komplexní $\mathrm{PCl}$ i překvapivé závěry.

Účast na SCAI Fall Fellows Courses 2011 mi byla umožněna díky České kardiologické společnosti a Pracovní skupině intervenční kardiologie ČKS. Kongres považuji za velice přínosný a prakticky orientovaný, neocenitelná je také možnost kontaktů s intervenčními kardiology z různých koutů světa a porovnání úrovně znalostí a technik v oboru intervenční kardiologie.

MUDr. David Vindiš,

I. interní klinika - kardiologická, Lékařská fakulta Univerzity Palackého

a Fakultní nemocnice Olomouc, Olomouc, e-mail: davidvindis@seznam.cz 